\title{
O mito da impessoalidade na redação oficial
}

\author{
José Augusto Guerra
}

Texto publicado na RSP, vol. 105, no 1, de jan./abr. de 1970.

\begin{abstract}
O texto da seção RSP Revisitada desta edição é de José Augusto Guerra, professor de Redação de Jornalismo da Universidade de Brasília, no início da década de 1970. O artigo trata da necessidade de compreender a correspondência oficial como mecanismo eficaz para comunicação. Guerra acredita que exista uma arte de comunicar, embora se cometam tantos erros ao se seguir normas de aço na redação. Ele cita Penteado (1964) ao listar os principais enganos na comunicação escrita: a força da tradição, o desejo de impressionar e o fato de não se pensar bem antes de escrever. Como principal exemplo de naturalidade, objetividade e eficiência no universo da linguagem oficial, Guerra cita os relatórios de Graciliano Ramos, na época em que era prefeito em Palmeira dos Índios, município do interior de Alagoas. Essas peças informativas clássicas entrariam para a história da redação oficial brasileira como exemplo de renovação e clareza da informação. 0 artigo, escrito no auge do Regime Militar, surpreende ao vir ao encontro da Lei no 12.527, conhecida como Lei de Acesso à Informação, promulgada em 2011. Essa legislação, tão democrática quanto os tempos atuais, prega a gestão transparente, objetiva e clara da informação, propiciando amplo acesso a ela e sua divulgação, primando, sobretudo, por uma linguagem oficial de fácil compreensão para o cidadão comum.
\end{abstract}

Mais de um técnico em administração pública tem-se ocupado da linguagem com que no mundo dos memorandos, das cartas e dos ofícios os funcionários públicos se comunicam. Trata-se de uma arte, a da correspondência oficial, que obedece a umas tantas normas específicas, desde a escolha do papel, pelo tamanho e qualidade, às expressões que distinguem a autoridade em sua grandeza hierárquica. Isto sem falar nas fórmulas, por vêzes inflexíveis, com que se inicia ou se termina qualquer documento. 
Na verdade, a linguagem oficial, vasto mundo impresso em que se determina isto e aquilo, e isto e aquilo devem ser cumpridos, está a exigir mais de um estudioso e não só o técnico da expressão escrita.

\section{Os manuais de redação}

Os livros dos Srs. João Luiz Ney e Odacyr Beltrão ${ }^{1}$, sôbre a correspondência oficial, como se fôssem manuais de consultas, oferecem uma visão geral do que é êsse universo da comunicação por escrito. Confessa o autor de Prontuário de Redação Oficial que não teve nenhuma intenção de escrever um livro. Tendo recebido a incumbência de organizar uma antologia de documentos oficiais, destinada às aulas de Português e Redação Oficial do então Departamento Administrativo do Serviço Público, isto num prazo curto de 20 dias, logo se entusiasmou com a tarefa. E do que seria simples apostila saiu um livro: "Não obstante a pressa que se impunha, o trabalho assumiu proporções além do plano preestabelecido para uma simples antologia e resolvi transformá-lo num manual ou prontuário de redação oficial".

Por sua vez, o Sr. Odacyr Beltrão partiu de uma idéia que Ihe serviu provavelmente de ponto de apoio para a elaboração do livro, já na 10a edição. Diz em nota explicativa: "A Correspondência deixou de ser um todo isolado ou mero complemento das aulas de gramática formal, para situar-se definidamente na Comunicação escrita."

\section{O tema pessoal}

São livros rigorosamente técnicos. Mas as observações, as recomendações, os modelos que nêles se encontram a propósito do aspecto estilístico na correspondência oficial, mostram que os diversos documentos que a compõem a ata, o atestado, o aviso, a carta, a circular, o contrato, o edital, a exposição de motivos, o memorando, a mensagem, o ofício, o parecer, o relatório, o requerimento e o telegrama - embora rigorosos em sua estrutura material, não dispensam certos requisitos de seus autores. Um dêles, dos mais importantes, seria o toque pessoal na maneira de expressar.

\footnotetext{
${ }^{1}$ Ney, João Luiz - Prontuário de Redação Oficial - Edição do DASP, Rio, 1955. Beltrão, Odacyr - Correspondência: Linguagem e Comunicação, Editôra Atlas, São Paulo, 10a ed., 1966.
} 
Ora, êsse toque pessoal que se recomenda, na realidade, praticamente não é estimulado. Somos, por tradição, tão apegados à letra que ainda hoje se os governantes não recebem, ao fecho das exposições e ofícios, o beija-mão com que Vaz Caminha concluiu sua famosa carta a D. Manuel - "Beijo a mão de Vossa Alteza"2 - continua-se a apresentar ou a renovar "os protestos da mais alta estima e distinta consideração". Ainda que no corpo de um ofício trate-se de uma refutação a uma inverdade, com laivos de descompostura em têrmos corteses ou um destampatório com tendência à polêmica, o fecho é sempre tão altaneiro que se fica em dúvida quanto à distinção, à estima, à consideração e, certamente, à razão dos renovados protestos.

Por que ainda nos espichamos nesses rapapés sonoros (que perderam muito a solenidade dos primeiros tempos), rapapés que tornam a prosa suntuosa nesses tempos de objetividade e concisão? Creio que não cabe exclusivamente ao técnico em redação oficial responder à pergunta. É um tema a que ainda nenhum MacLuham ou Hayakawa se deteve em suas excogitações sôbre os destinos da comunicação humana na área administrativa. Na verdade, tão sério o problema do ponto de vista psicológico, que a ausência de um adjetivo honorífico, o lapso na troca de um V. Exa por V. Sa , uma falha datilográfica na margem direita ("a sagrada linha imaginária não pode ser passada - e que o datilógrafo se arranje como puder", observa, com humor, o Sr. Odacyr Beltrão), têm provocado tempestades terríveis entre chefes e subordinados, e, não raro, dores de cabeça, amuos e lágrimas. Mais de uma datilógrafa certamente em suas memórias, se as escrevesse, teria o que contar, a propósito de incidentes provocados por erros ou omissões na feitura da correspondência oficial.

É certo que em nossa bibliografia temos um autor, dos melhores, que tocou no assunto numa linguagem didática que merece leitura e releitura. Refiro-me ao Sr. J. R. Whitaker Penteado ${ }^{3}$. No capítulo sôbre A Arte de Escrever, ao perguntar Por que se escreve mal?, responde, enumerando três razões: "1) a tradição; 2) o desejo de impressionar; 3) não sabemos pensar bem". Evidente que êsses três itens se entrelaçam. Mas, com respeito à primeira das razões, diz o autor que ao gongorismo se deve debitar "essa linguagem pesada, repleta de analogias figurativas, vocabulário escasso e forma obscura". E acrescenta: "Essa tradição de

\footnotetext{
${ }^{2}$ Cortesão, Jayme - Cabral e as Origens do Brasil - Edição do Ministério das Relações Exteriores, Rio, 1944.

${ }^{3}$ Penteado, J. R. Whitaker - A Técnica da Comunicação Humana - Liv. Pioneira Editôra, São Paulo, 1964.
} 
escrever mal cristalizou-se, na linguagem formal dos documentos públicos, petições e arrazoados" (pág. 220).

$\mathrm{Na}$ verdade, antes do gongorismo, em fins do século XVI, já houve quem embirrase com êsse palavreado dos documentos jurídicos, com a fina ironia de quem, sabendo escrever, repugnava-se com os trejeitos de qualquer prosa cheia de sinuosidades. Chamava-se Montaigne. Numa de suas anotações, comentou: "Por que nossa linguagem comum, tão cômoda e fácil, se torna obscura e ininteligível, quando empregada em contratos e testamentos? Por que os que se exprimem tão claramente quando falam ou escrevem, não acham jeito de não se confundir ou se contradizer em atos dêsse gênero?" Pelo prazer de tornar mais complicadas as coisas simples, concluía Montaigne: "É sem dúvida porque os príncipes dessa arte se aplicam com especial cuidado em escolher vocábulos solenes, frases artisticamente construídas, e tanto pesam cada sílaba, sutilizam cada têrmo, que nos embaraçam e embrulham na multiplicidade das fórmulas e das minúcias; e não mais distinguimos regras ou prescrições e não entendemos absolutamente mais nada"4.

Claro que a distância entre uma procuração, um contrato de compra e venda e um ofício, é enorme. Mas essa distância se torna curta e quase desaparece quando, fazendo-se abstração da estrutura dêsses documentos, passa-se a examiná-los do ponto de vista da expressividade. Ou melhor, da comunicabilidade. Sob êsse aspecto, tanto um ofício como um telegrama, uma exposição de motivos ou um parecer, podem tornar-se ininteligíveis porque redigidos em linguagem arrevesada.

\section{Em busca da comunicabilidade}

É portanto, a comunicabilidade, um dos aspectos fundamentais da redação oficial. Em seu livro, o Sr. Odacyr Beltrão pede um lugar de relêvo para a composição epistolar, porquanto, "se o soneto anda em cárcere de aço, o ofício tem seu molde de ferro". Mas reconhece que na linguagem oficial "há têrmos e expressões sem qualquer proveito prático e fechos extensos demais ou redundantes, quando não contrastam seus elementos" (pág. 43).

\footnotetext{
${ }^{4}$ Montaigne, Michel de - Ensaios - Trad. de Sérgio Milliet, Livro III, cap. 13, Da Experiência, Ed. Globo, Pôrto Alegre, 1961.
} 
Embora professôres e técnicos reconheçam a pobreza a que tem chegado o estilo administrativo, numa época em que se fala tanto em comunicação, no tornarse comunicável, na comunicabilidade, e noutras expressões, de tal modo que os novos profetas da automação parecem criar uma nova religião do homem com base no computador, êste nôvo deus, já reverenciado por Carlos Drummond de Andrade ${ }^{5}$, a linguagem oficial, por fôrça do hábito e da tradição, continua uniformizada em ruidosas expressões e fechos grandiloqüentes que, pelo excesso de impessoalidade, tanto pode conduzir alguém ao céu como jogá-lo nas profundezas do inferno.

Não tenho a intenção de sugerir ou mesmo insinuar que se vire pelo avêsso a comunicação oficial. Mas seria de bom aviso que certas entidades tão empenhadas no aprimoramento dos esquemas da comunicação oficial, do ponto de vista tecnológico, meditassem sôbre uma idéia que, como colaboração, ofereço: a de se modificar a linguagem escrita da correspondência oficial, tornando-a mais conforme o pensamento e a fala.

Quando o Sr. Odacyr Beltrão citando O Dirigente Industrial, de março de 1960, concorda em que "um relatório bem escrito é aquêle que contém todas as informações e nenhum pormenor supérfluo" (pág. 173), isto nos lembra o que de Tchecov a Maupassant, de Machado de Assis a Hemingway vem-se afirmando sôbre a arte do conto: uma narrativa com o máximo de objetividade. Ou, mais particularmente, as recomendações que se fazem aos estudantes de jornalismo, para que sejam breves, escrevam frases curtas, utilizem o estilo direto, usem expressões que todos conhecem, e assim por diante ${ }^{6}$. De certo modo, que se faz quando se redige um ofício, uma ata, um aviso, uma circular, uma exposição de motivos, uma mensagem ou se emite um parecer, ou lavra-se uma sentença, senão transmitir uma informação ou dar uma opinião? Será conveniente que o redator, informando ou opinando seja claro, objetivo, sem redundâncias nem reticências. Imaginemos um simples aviso ou ordem de serviço em têrmos arrevesados. É provável que ninguém entenda o que está escrito ou que suscite tantas interpretações, quantos intérpretes do texto. Se formos um dia respigar na legislação vigente o que existe de incompreensível em artigos e parágrafos, quando não contraditório e conflitante, veremos que a clareza a que se referia Anatole

\footnotetext{
${ }^{5}$ Andrade, Carlos Drummond de - Poema intitulado Ao Deus Kom Unik Hassão, Jornal do Brasil, Rio, 20 caderno.

${ }^{6}$ A propósito dessas recomendações, Ernest Hemingway costumava dizer: "Essas regras foram as melhores que aprendi sôbre a arte de escrever. Jamais as esqueci. Nenhum homem de talento, que sente e escreve honestamente sôbre o fato que está querendo descrever, pode deixar de escrever bem se as observar". Referia-se aos princípios de redação de notícias do Star, de Kansas City, onde trabalhou.
} 
France, primeira, segunda e terceira virtudes do escritor, não se aplica apenas à literatura de ficção mas à arte de comunicar o que se pensa.

\section{Dois relatórios famosos}

Enquanto não amadurece a idéia de termos uma linguagem burocrática mais afim com a época atual - e é bom lembrar que a linguagem varia de acordo com a época - pois muito antes de Montaigne muita pena de pato se encarrapichou em contacto com a formulação protocolar, sugiro ao futuro renovador da linguagem oficial (que certamente será técnico renomado e a quem caberá, por decreto ou portaria, a incumbência de organizar grupo de trabalho para tão espetacular emprêsa) a leitura de dois documentos de um só autor: os relatórios do Prefeito Graciliano Ramos ao Governador Álvaro Paes, de Alagoas

Os relatórios, de 1928 e 1929, já estão incorporados à nossa história literária. O próprio Graciliano Ramos, em entrevista a Homero Senna ${ }^{8}$, narrou o que aconteceu. Não imaginava o Prefeito de Palmeira dos Índios que tais documentos provocassem tanto barulho. Eram simples exposições dando conta de uma simples administração municipal. Tomando conhecimento do primeiro relatório, Augusto Frederico Schmidt, então editor, entrou em contacto com Graciliano Ramos, pedindo-Ihe que enviasse artigos para a imprensa. "Como não me interessasse fazer carreira no jornalismo, nem construir nome literário, recusei-me", esclareceu mais tarde Graciliano. Mas, em vez de remeter artigos, enviou o romance Caetés, que certamente já estava há anos escrito. Acredite-se ou não no faro literário de Augusto Frederico Schmidt, a verdade é que Graciliano tinha na gaveta os originais de Caetés e - como diria Paulo Honório - encoivarava São Bernardo, aos sábados, à tarde, à sombra do oitão da matriz de Palmeira dos Índios.

Que há de renovador na linguagem do Prefeito Graciliano Ramos? Relatório é relatório. Os de Graciliano Ramos não fogem da perspectiva dos acontecimentos oficiais e oficiosos. "Apenas - disse a Homero Senna - como a linguagem não era a habitualmente usada em trabalhos dessa natureza, e porque nêles eu dava às coisas seus verdadeiros nomes, causaram um escarcéu medonho."

\footnotetext{
${ }^{7}$ Ramos, Graciliano - Viventes das Alagoas - Liv. Martins Editôra, São Paulo, 1962.

${ }^{8}$ Senna, Homero - República das Letras - (Entrevistas) - Gráfica Olímpica Editôra, 2a edição, Rio, 1968.
} 
Vamos aos relatórios. A rigor, a introdução de ambos lembra o tratamento ascético da epistolografia da época dos descobrimentos. Na correspondência de Martim Affonso de Souza, Duarte Coelho e Tomé de Souza ao Rei de Portugal, logo após o vocativo Senhor (sem antecedê-lo do epíteto ilustre ou muito menos ilustríssimo), segue-se sem rodeios o que desejam expor ${ }^{9}$.

Em Graciliano Ramos, depois do Exmo. Sr. Governador no 1을 Relatório e Senhor Governador no 2ำ Relatório, dispensando os preâmbulos tão usuais, o Prefeito inicia logo a narrativa e põe o leitor à vontade, numa linguagem que, percebe-se, nada tem de semelhante ao pomposo e nefelibático estilo administrativo. A proporção que o Prefeito narra o que fez e o que não fez, as ações e as omissões, em vez do escriba oficial apegado aos cânones, temos um discípulo de Montaigne discorrendo sôbre as vantagens e desvantagens da administração, numa linguagem coloquial. Exatamente êsse coloquial, temperado de finas observações sobre a vida social do Município, provocou certo escândalo. Porque, de fato, só faltou ao Senhor Prefeito designar pelos nomes os personagens cobradores de impostos, políticos, fazendeiros - figuras de proa de muitos episódios.

Quarenta anos passados ainda é válido o convite: quem vier a ler ou reler os relatórios de Graciliano Ramos observe os parágrafos iniciais:

No 1을 Relatório, de janeiro de 1929:

Exmo. Sr. Governador:

Trago a V. Exa um resumo dos trabalhos realizados pela Prefeitura de Palmeira dos Índios, em 1928.

Não foram muitos, que os nossos recursos são exíguos. Assim minguados, entretanto, quase insensíveis ao observador afastado, que desconheça as condições em que o Município se achava, muito me custaram.

No 2ำ Relatório, de janeiro de 1930:

Sr. Governador:

Esta exposição é talvez desnecessária. O balanço que remeto a V. Ex.a mostra bem de que modo foi gasto em 1929 o dinheiro da Prefeitura Municipal de Palmeira dos Índios. E nas contas regularmente publicadas há

\footnotetext{
${ }^{9}$ Tapajós, História Administrativa do Brasil, Vol. II - Edição do DASP, Rio, 1956.
} 
pormenores abundantes, minudências que excitaram o espanto benévolo da imprensa.

Isto é, pois, uma reprodução de fatos que já narrei, com algarismo e prosa de guarda-livros, em numerosos balancetes e nas relações que os acompanharam.

Para o Prefeito Graciliano Ramos, traduzir em palavras o que já havia sido exposto antes, "com algarismo e prosa de guarda-livros", seria provàvelmente chover no molhado. Daí o inopinado da expressão inicial: "Sr. Governador: Esta exposição é talvez desnecessária."

E por ser desnecessário transformar a "prosa de guarda-livros" noutra prosa ainda mais convencional, é que os relatórios resultaram numa narrativa a que não falta o pitoresco sublinhando as providências administrativas.

No Relatório de 28, começa por dizer que Palmeira dos Índios, Município de recursos pobres, não permitia trabalhos grandiosos. O principal, contudo, era "estabelecer alguma ordem na administração". Alguma ordem, diz a autoridade, porque em Palmeira dos Índios quase todos mandavam. A meu ver, nenhuma "prosa de guarda-livros" (e, por extensão, de correspondente especialista em linguagem oficial) seria capaz de narrar essas dificuldades iniciais com traços de fino humor, onde o ritmo da frase é bem do escritor, já afiado na técnica da narrativa.

Havia em Palmeira inúmeros prefeitos: os cobradores de impostos, o comandante do destacamento, os soldados, outros que desejassem administrar. Cada pedaço do Município tinha a sua administração particular, com prefeitos-coronéis e prefeitos-inspetores de quarteirões. Os fiscais, êsses, resolviam questões de polícia e advogavam.

Que fazer? O nôvo Prefeito não esconde as dificuldades:

Para que semelhante anomalia desaparecesse, lutei com tenacidade e encontrei obstáculos dentro da Prefeitura e fora dela - dentro, uma resistência mole, suave, de algodão em rama; fora, uma campanha sôrna, oblíqua, carregada de bílis. Pensavam uns que tudo ia bem nas mãos de Nosso Senhor, que administra melhor do que todos nós; outros me davam três meses para levar um tiro.

Dos funcionários que encontrei em janeiro do ano passado restam poucos: saíram os que faziam política e os que não faziam coisa nenhuma. Os atuais não se metem onde não são necessários, cumprem as suas obrigações e, sobretudo, não se enganam em contas. Devo muito a êles. 
E, arrematando, êste trecho muito semelhante aos solilóquios de Paulo Honório ou Luís da Silva, personagens de São Bernardo e Angústia:

Não sei se a administração do Município é boa ou ruim. Talvez pudesse ser pior.

\section{A impessoalidade}

Só isto, creio, é suficiente para se perceber até onde a linguagem de Graciliano Ramos difere da linguagem dos relatórios geralmente vazados em estilo administrativo. Pode-se objetar que, permitindo-se ao redator oficial certa liberdade de expressão, de modo a romper o "molde de ferro" da composição epistolar, corre-se o risco de, abandonando-se a impessoalidade do estilo administrativo, cair na subliteratura. Como nem todos possuem o jeito, o dom de escrever, a quebra dos cânones resultaria no renascimento de estilos que, escapando do convencional, tornar-se-iam excessivamente pessoais e desfigurariam, de certo, a objetividade do esquema epistolar administrativo, para o qual, segundo o Sr. João Luiz Ney, apenas três qualidades são necessárias: correção, clareza e concisão. A harmonia, a originalidade e o vigor, segundo o autor de Prontuário de Redação Oficial, são dispensáveis.

Nem tanto nem tão pouco. Nem a impessoalidade levada ao extremo, a ponto de se cristalizar em expressões que há muito perderam o viço, nem a liberdade irresponsável de querer transformar uma simples informação numa página de lances literários. De resto, quem está enfronhado nesses assuntos percebe que nem tudo no estilo administrativo é impessoal. Nada mais exige o toque pessoal para dizer e convencer, do que uma exposição de motivos ou a justificativa a projeto de lei. $E$ nada menos convincente que um memorial ou um parecer em que, de alto a baixo, os lugares comuns reflitam a insensaboria, quando não a inépcia de quem, fora dos chavões, não sabe alinhavar idéia. Pessoalmente, não dou excessivo crédito à impessoalidade. A meu ver, até mesmo um parecer de três linhas pode trazer a marca pessoal de quem o emite, sem o menor prejuízo para a redação oficial.

\section{Estrutura e renovação}

Ora, o Prefeito Graciliano Ramos não inovou a técnica dos relatórios (convém lembrar que se trata de documentos dos idos de 30), do ponto de vista estrutural. Após o preâmbulo, já citado, os diversos itens obedecem ao esquema expositivo tradicional, de acordo com os entretítulos: Receita e Despesa - Poder Legislativo Iluminação - Obras Públicas - Eventuais - Cemitério - Escola de Música - 
Funcionários da Justiça e da Polícia - Administração - Estrada de Fora - Terrapleno da Lagoa - Dinheiro Existente, até o item final: Conclusão. O que tornou os relatórios famosos, hoje citados em qualquer conversa sôbre a prosa de Graciliano Ramos, foi a arte de dizer, personalíssima, em cada item. Ao esclarecer, por exemplo, que a receita, em contos de réis, orçada em ..... . 50:000\$000 subiu a 71:649\$290, apressase em dizer que tais recursos

não foram sempre bem aplicados por dois motivos: porque não me gabo de empregar dinheiro com inteligência e porque fiz despesas que não faria se elas não estivessem determinadas no orçamento.

A propósito de Despesas Eventuais, em que justifica o gasto de alguns mil réis para uniformizar pesos e medidas, entra em considerações:

Os litros aqui tinham mil e quatrocentas gramas. Em algumas aldeias subiam, em outras desciam. Os negociantes de cal usavam tábuas para enganar o comprador. Fui descaradamente roubado em compras de cal para os trabalhos públicos.

Mas, realmente antológico é o registro dos gastos com o cemitério, em decorrência da relação entre o adjunto adverbial e o verbo:

No cemitério enterrei $189 \$ 000$ - pagamento ao coveiro e conservação.

Por fim o fecho em que, pelo estilo, se assemelha ao que de melhor se encontra na prosa de Graciliano Ramos:

Não favoreci ninguém. Devo ter cometido numerosos disparates. Todos os meus erros, porém, foram erros da inteligência, que é fraca.

Perdi vários amigos ou indivíduos que possam ter semelhante nome.

Não me fizeram falta.

Há descontentamento. Se a minha estada na Prefeitura por estes dois anos dependesse de um plebiscito, talvez eu não obtivesse dez votos.

No segundo relatório, entre informações com que justifica a aplicação da receita (a maior das preocupações do Prefeito Graciliano Ramos era não desperdiçar dinheiro), faz comentários, um dêles sôbre as condições da sede municipal, com observações de admirável riqueza sociológica:

Dos administradores que me precederam, uns dedicaram-se a obras urbanas; outros, inimigos de inovações, não se dedicaram a nada.

Nenhum, creio eu, chegou a trabalhar nos subúrbios.

Encontrei em decadência regiões outrora prósperas; terras aráveis entregues a animais, que nelas viviam quase em estado selvagem. A população minguada, ou emigrava para o sul do País ou se fixava nos municípios vizinhos, nos povoados que nasciam perto das fronteiras e que 
eram para nós umas sanguessugas. Vegetavam em lastimável abandono alguns agregados humanos.

E o palmeirense afirmava, convicto, que isto era a princesa do sertão. Uma princesa, vá lá, mas princesa muito nua, muito madraça, muito suja e muito escavacada.

Favoreci a agricultura livrando-a dos bichos criados à-toa; ataquei as patifarias dos pequeninos senhores feudais, exploradores da canalha; suprimi, nas questões rurais, a presença de certos intermediários, que estravagam tudo; facilitei o transporte; estimulei as relações entre o produtor e o consumidor.

Estabeleci feiras em cinco aldeias. 1:157\$750 foram-se em reparos nas ruas de Palmeira de Fora.

Canafístula era um chiqueiro. Encontrei lá o ano passado mais de cem porcos misturados com gente. Nunca vi tanto porco.

Desapareceram. E a povoação está quase limpa. Tem mercado semanal, estrada de rodagem e uma escola.

Sòmente um escritor teria condições de transformar a linguagem fria dos números numa exposição a que hoje se recorre com o interêsse de quem busca, não o relatório de um romancista famoso, mas o relatório famoso de um ex-prefeito de cidadezinha do interior alagoano, que em sua curta passagem pela administração pública deixou a lição de como redigir documento oficial sem ficar emparedado pela redundância das frases feitas.

\section{A vulgarizaçao da palavra}

Observa-se hoje como a incidência, o repisado numa formulação uniforme, seja no fecho, no corpo ou na introdução do documento, vem resultando na vulgarização da palavra, que termina perdendo seu sentido interior. Que os elementos de que se compõe, por exemplo, um ofício, sejam uniformizados, compreende-se. E que elementos são êsses? Elementos de identificação e que formam o "espelho" de um ofício, desde a indicação da sede da repartição (cabeçalho ou timbre), até, após a assinatura, o enderêço do destinatário e as iniciais do redator e do datilógrafo.

Conta o Sr. Odacyr Beltrão, no livro citado, que certa vez perguntaram a um aluno por que motivo êle se inscrevera no curso de correspondência com o nome de Ilmo. José da Silva. Êle respondeu: “Ora, professor, achei que podia usar isso, por que todos lá no escritório escrevem sempre ilmo isso, ilmo aquilo". Esta 
anedota mostra até que ponto estamos habituados ao chavão ou à impropriedade, embora muitos reconheçam - e cito o Sr. João Luiz Ney - que, embora existam algumas chapas na correspondência oficial, haja vista os fechos de cortesia, são "oficialmente impostas" (pág. 64).

Apesar de se reconhecer a necessidade de atualizarmos a linguagem oficial, a partir dos vocativos, ainda hoje o Prezado Senhor é expressão obrigatória mesmo quando êste Senhor a quem se dirige o remetente é um ilustre desconhecido. Provàvelmente, devido ao abuso com que se usa o epíteto ilustre e seus derivados, é que há vários anos, no jornalismo, foi êle definitivamente banido. Ninguém é ilustre ou ilustre se torna numa notícia de jornal. No entanto, todos somos ilustres numa correspondência comercial, mesmo quando o banco nos avisa que se encontra para cobrança um título nosso, com vencimento em tal dia do mês passado.

Já estamos tão habituados a certas expressões - Tenho a honra de comunicar a V. Exa. - que o próprio vocábulo honra já perdeu todo o significado. Será uma honra comunicar a alguém uma rotineira ocorrência administrativa? $E$, quando se trata de comunicar, seria honroso solicitar de alguém alguma coisa, por vêzes uma simples informação?: Tenho a honra de solicitar a V. Exa....

Por que continuamos a insistir no Apraz-me acusar o recebimento de tal ofício, quando, muitas vêzes, a informação que se deve prestar não resulta (para sermos fiéis à derivação) em nenhum aprazimento? E, por que, noutros casos, o Rogo a V. Exa. a gentileza de, quando a rigor, não há rogo, mas ordem, determinação, e o não-cumprimento da gentileza resultará, inapelàvelmente, em infringência das normas administrativas?

Não há requerimento expedido a qualquer repartição em que o requerente, humilíssimo, não deixe de apelar para que V.Sa. se digne mandar pagar ou se digne autorizar a expedição de tal documento. Para simples confronto, em termos de propriedade vocabular, vale a pena citar o texto de Vieira: "E David contava e contava por grande maravilha, que estando Deus tão alto, Se dignasse de olhar cá para baixo e pôr os olhos na Terra"10.

Já é tempo de se pensar numa atualização do chamado estilo oficial, tão desenxabido, e de tão profunda falta de imaginação, que alguns candidatos consideram melhor decorar as fórmulas que aprimorar-se na técnica da narrativa.

${ }^{10}$ Vieira - Sermões, Tomo IV, - Sermão do Mandato - Lello Irmãos Editôres - vol. II pág. 413. 
Não vemos por que continuarmos presos a fórmulas já inexpressivas, quando, sem perda da cortesia e sem detrimento dos níveis hierárquicos, possuímos palavras e expressões mais atualizadas.

Parece, contudo, que algo de nôvo está surgindo e que terminará inclinando todo o esquema da correspondência oficial para um processo mais objetivo e nada redundante na expressão. Vêm causando surprêsa os pronunciamentos do Presidente Emílio Médici, pela sua linguagem nada protocolar, nas mensagens e discursos que tem proferido. Fugindo do estilo convencional são documentos em que há fortes traços literários - de boa literatura que em nada prejudica o que quer que se deseje comunicar. Excelente começo, considerando-se principalmente a origem do exemplo, vindo do alto.

Resta-nos esperar que, desataviando-se a correspondência oficial dos moldes rotineiros, crie-se, enfim, um espírito de renovação na arte que, embora não devidamente valorizada exige, antes de tudo, uma prosa exata e enxuta, sem os atavios que a tornam inexpressiva exatamente por sua falsa e fátua grandiloqüência. 